\title{
ІНТЕГРАЦІЯ ВИЩОЇ МЕДИЧНОЇ ОСВІТИ ДО ЄВРОПЕЙСЬКИХ СТАНДАРТІВ
}

\author{
В. Й. Шатило
}

Вінницький національний медичний університет імені М. І. Пирогова,

Житомирський інститут медсестринства

\section{INTEGRATION OF HIGHER MEDICAL EDUCATION TO EUROPEAN STANDARDS}

\author{
Vinnytsya National Medical University by M. I. Pyrohov, \\ Zhytomyr Institute of Nursing
}

\author{
V. Y. Shatylo
}

\begin{abstract}
У статті на прикладі Житомирського інституту медсестринства висвітлено переваги і проблеми запровадження вищої медичної освіти в Україні відповідно до європейських стандартів.
\end{abstract}

Advantages and problems of introduction of higher medical education in Ukraine in accordance with the European standards on the example of Zhytomyr Institute of Nursing are reflected in the article.

Вступ.Процес об'єднання Європи супроводжується формуванням спільного освітнього і наукового простору та розробкою єдиних критеріїв і стандартів у всіх сферах, у тому числі й в освітній, що й було задекларовано Україною в основних документах Болонських угод. Головна мета Болонського процесу - інтеграція зусиль наукової та освітянської громадськості й урядів країн Європи для істотного підвищення конкурентоспроможності європейської системи науки і вищої освіти у світовому вимірі [1-4].

В українській системі медсестринської освіти $\epsilon$ чимало цінностей, якими можна пишатися, які $\epsilon$, у певному розумінні, вічними, оскільки відображають одвічне прагнення людини до любові, краси і добра. Однак наша нова історія, де суспільні відносини будувалися на ізоляціонізмі, де за останні сто років п'ять разів винищувалася інтелігенція, не могла не привести до певних ціннісних деформацій у системі освіти [2].

Основна частина. Метою дослідження $є$ аналіз та узагальнення перспективних підходів до удосконалення підготовки медичних сестер за кредитномодульною системою. Для досягнення мети використано контент-аналіз законодавчих нормативних документів та медико-соціологічне дослідження (анкетування).

Головною ідеєю Болонської конвенції є стандартизація підходів до організації навчального процесу та

(c) В. Й. Шатило функціонування вищої школи в Свропі з метою гармонізації національних освітніх систем вищої освіти та підвищення конкурентоспроможності вищих навчальних закладів Старого світу порівняно з університетами інших регіонів планети, головним чином США.

Основні положення Болонської декларації

-Прийняття системи порівняльних ступенів, у тому числі шляхом запровадження додатка до диплома для забезпечення можливості працевлаштування європейських громадян і підвищення міжнародної конкурентоспроможності європейської системи вищої освіти.

- Введення двоциклового навчання: попереднього (pregraduate) і випускного (graduate). Перший цикл триває не менше трьох років та завершується отриманням ступеня бакалавра. Другий повинен вести до отримання ступеня магістра або кандидата наук.

- Впровадження європейської системи трансферу для підтримки студентської мобільності (система кредитів). Вона також забезпечує право вибору студентом дисциплін. За основу пропонується прийняти ECTS (European Credit Transfer System), зробивши iï накопичувальною системою, здатною працювати в рамках концепції “навчання впродовж усього життя”.

- Розширення мобільності викладацького персоналу та запровадження стандартів транснаціональної освіти. 
- Сприяння європейському співробітництву в забезпеченні якості з метою вироблення порівняльних критеріїв і методологій.

- Впровадження вузівських систем контролю якості освіти та залучення до зовнішньої оцінки діяльності вузів студентів та роботодавців.

- Сприяння європейським підходам у вищій освіті, особливо в галузі розвитку навчальних планів, спільних програм навчання, практичної підготовки і проведення наукових досліджень.

На всіх етапах підписання угод було проголошено, що цей процес грунтується на цінностях європейської освіти та культури, а також враховує і зберігає національні особливості освітніх систем різних країн Європи.

Одним з інструментів реалізації цілей Болонського процесу є запровадження кредитно-модульної системи (КМС), яка допомагає вищим навчальним закладам досягти забезпечення якості освіти у світлі євроінтеграції.

Аналіз 5-річного досвіду впровадження кредитномодульної системи у КВНЗ “Житомирський інститут медсестринства” дозволив виявити такі переваги порівняно з традиційною системою навчання:

- підвищення мотивації студентів до навчання;

- контроль викладача при опануванні практичних навичок та вмінь на кожному занятті;

- організація навчання, за якої враховуються інтереси і здібності студентів;

- впровадження рейтингової шкали ECTS відображає більш об'єктивне оцінювання успішності студентів;

- значна активізація та оновлення методичнонавчального забезпечення (створення типових програм, нових навчально-методичних посібників, тематичних збірників тестів, ситуаційних задач тощо);

- розміщення на сайтах навчальних закладів навчально-методичних матеріалів, що дає змогу студентам застосувати інноваційне дистанційне навчання та значно активізувати самостійну роботу студента; - зниження вірогідності конфліктів, які можуть виникати в результаті підсумкової перевірки знань.

Зміни в організації навчального процесу у КВНЗ “Житомирський інститут медсестринства", які відбулися внаслідок оптимізації та покращення якості освіти:

1) введено єдину універсальну шкалу перерахунку традиційних оцінок 3 5-бальної системи у європейську бальну шкалу оцінювання, що значно зменшило кількість помилок при арифметичному підрахунку балів викладачами;
2) запроваджено індивідуальний план студента, який містить обов' язкову інформацію про результати всіх видів успішності;

3) навчальним процесом передбачено проведення підсумкового модульного контролю та по завершенню вивчення дисципліни - класичних іспитів;

4) розроблено програми навчальних дисциплін 3 урахуванням особливостей КМС; навчальну документацію обліку та оцінювання навчальних досягнень студентів; інформаційно-дидактичне забезпечення всіх елементів навчального плану по спеціальностях.

Позитивні зміни, які відбулися в результаті впровадження КМС у Житомирському інституті медсестринства, представлено на рисунках 1 і 2.

Аналіз результатів медико-соціологічного дослідження дозволив чітко визначити готовність як викладачів, так і студентів до роботи в кредитномодульній системі.

Готовність викладача до роботи у системі КМС (анкетування викладачів)

Питання: Які чинники впливають на стан готовності викладача до роботи у кредитно-модульній системі? - Потреба в поглибленні знань з предмета - 15 \%.

- Самодисципліна та самоорганізація - 1 \%.

- Володіння інноваційними технологіями навчання та виховання - $51 \%$.

-Організація пізнавальної діяльності студента-33\%.

Результати анкетування студентів КВНЗ “Житомирський інститут медсестринства”.

Питання: За якою системою Ви бажали б навчатись - традиційною або кредитно-модульною?

- Висловлюють за бажання повернутись до традиційної системи - $34 \%$.

За впровадження кредитно-модульної системи-66\%.

Переваги кредитно-модульного системного навчання (анкетування студентів)

Питання: Які переваги Ви вбачаєте у кредитномодульній системі навчання?

- Систематичність і послідовність в отриманні знань $-42,7 \%$.

-Можливість перескладання незадовільних оцінок $-7,1 \%$.

- Структурованість навчальної дисципліни на модулі $-12,7 \%$.

- Підвищення особистого рейтингу за рахунок додаткових завдань - 37,5\%.

Недоліки навчання за кредитно-модульною системою (анкетування студентів)

Питання: Які недоліки Ви вбачаєте у кредитномодульній системі навчання в порівнянні з традиційною системою? 


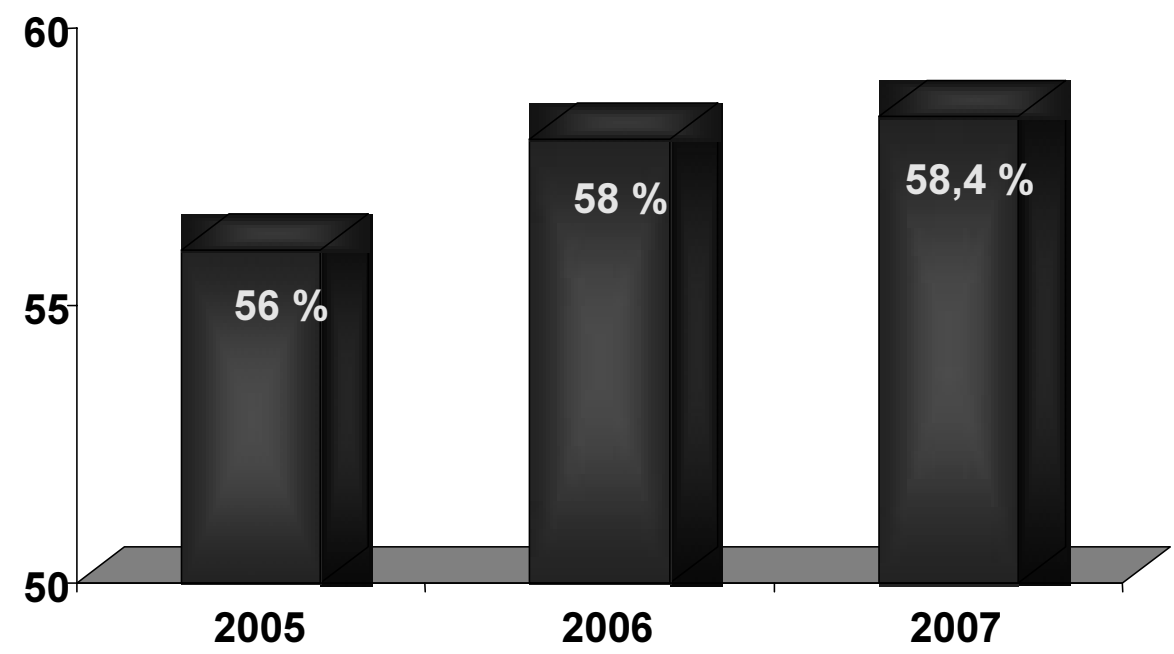

Puc. 1. Показники успішності навчання студентів до введення кредитно-модульної системи (до 2008 року) по навчальному закладу.

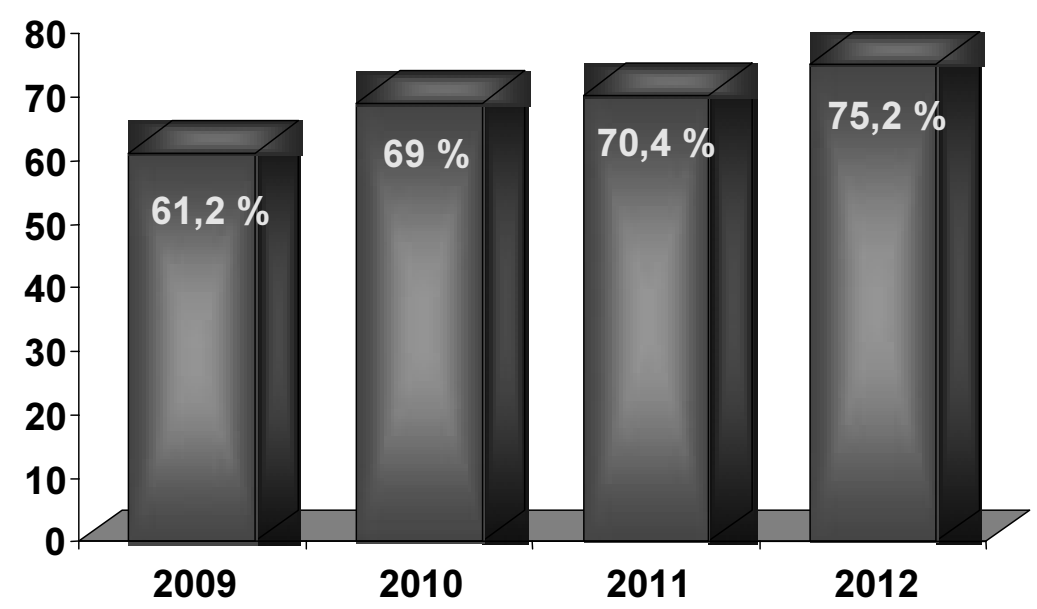

Puc. 2. Показники успішності навчання студентів після введення кредитно-модульної системи (після 2008 року) по навчальному закладу.

- Математичний розрахунок загального бала 3 дисципліни $-15,5 \%$.

- Тестовий контроль не дає адекватного оцінювання рівня знань $-22,8 \%$.

- Великий обсяг матеріалу, який виноситься на самостійне вивчення $-61,7 \%$.

Рейтингове місце чинників впливу на якість і адекватність самостійної роботи студентів за результатами опитування викладачів

1 місце. Розуміння студентами необхідності самостійної роботи.

2 місце. Попередня допомога з боку викладача в підготовці до самостійної роботи студентів.
3 місце. Контроль викладача за виконанням самостійних завдань.

4 місце. Забезпечення студента навчальними та методичними матеріалами.

Рейтингове місце чинників впливу на якість і адекватність самостійної роботи студентів за результатами анкетування студентів

1 місце. Контроль викладача за виконанням самостійних завдань.

2 місце. Забезпечення студента навчальними та методичними матеріалами.

3 місце. Розуміння студентами необхідності самостійної роботи.

4 місце. Попередня допомога з боку викладача в підготовці до самостійної роботи студентів. 
Вплив введення кредитно-модульної системи нарезультати ліцензійного інтегрованого іспиту “Крок-М" відділення "Лікувальна справа" КВНЗ “Житомирський інститут медсестринства” представлено на рисунку 3.

У 2012 році середній бал оцінювання знань студентів відділення "Лікувальна справа" інституту медсестринства перевищував середній показник по
Україні на 1,5%. У 2013 році середній бал студентів цього ж відділення перевищував середній показник по Україні уже на 4,7 \%. За кожним відсотком стоїть напружена праця студентів та викладачів інституту. При загальнодержавній тенденції до зниження якості підготовки фахівців лікувальної справи в Житомирському інституті медсестринства результати ліцензійного інтегрованого іспиту “Крок-М" із року в рік покращуються.

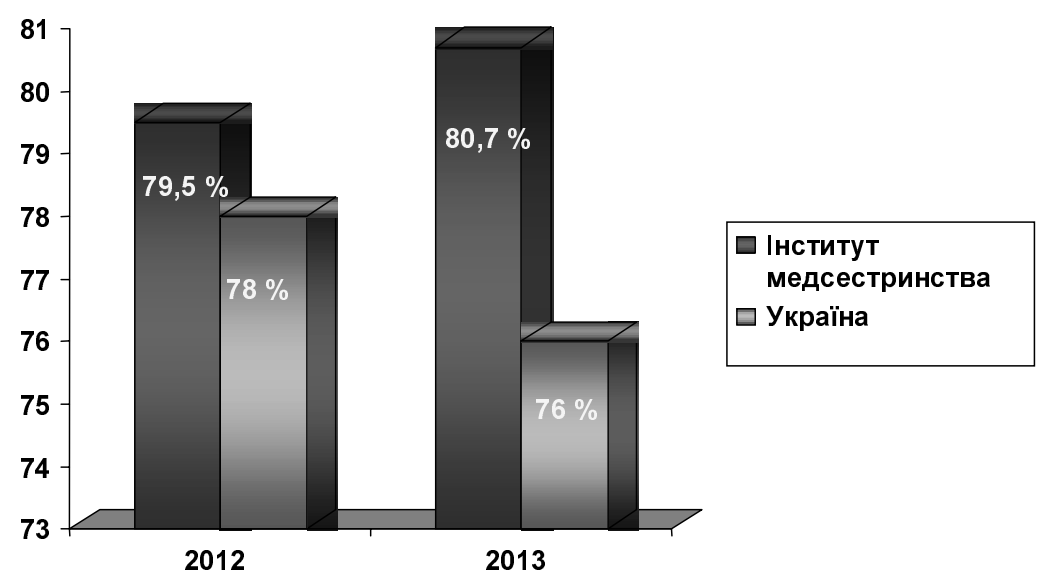

Puc. 3. Вплив введення КМС на результати ліцензійного інтегрованого іспиту “Крок-М” відділення “Лікувальна справа".

На рисунку 4 представлено вплив введення кредитно-модульної системи на результати ліцензійного інтегрованого іспиту “Крок-М” відділення “Сестринська справа” КВНЗ “Житомирський інститут медсестринства" впродовж останніх 3-х років.
Якщо у 2011 i 2012 pp. середній бал по інституту був дещо нижчим, ніж по Україні, то у 2013 році середній бал студентів відділення “Сестринська справа" інституту медсестринства перевищував середній показник по Україні на 2,7\%.

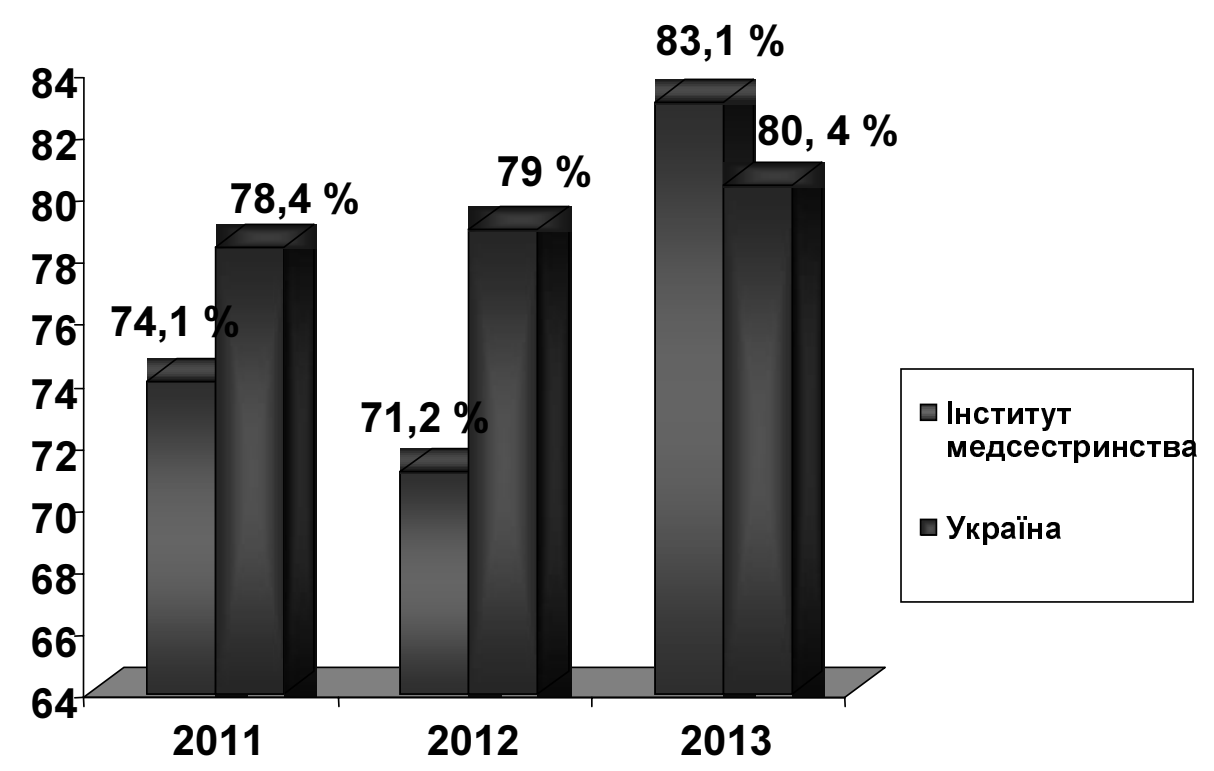

Puc. 4. Вплив введення КМС на результати ліцензійного інтегрованого іспиту “Крок-М” відділення "Сестринська справа". 
На рисунку 5 представлено динаміку показників ліцензійного інтегрованого іспиту “Крок-Б” на відділенні бакалаврату за спеціальністю “Сестринська справа” впродовж останніх 3-х років.

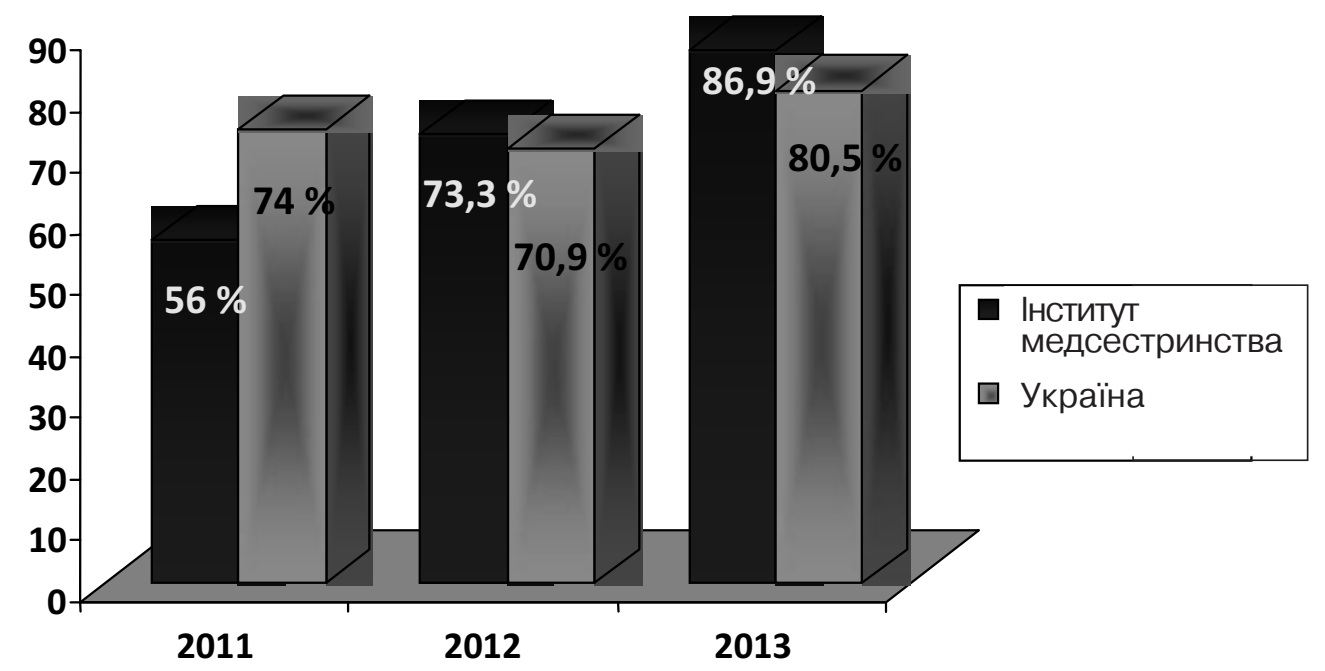

Puc. 5. Вплив введення КМС на результати ліцензійного інтегрованого іспиту “Крок-Б” за напрямом підготовки 6.120101 “Сестринська справа”.

Як і на інших відділеннях, починаючи з 2012 року, середній бал студентів-бакалаврів за спеціальністю "Сестринська справа" інституту медсестринства також перевищував середній показник по Україні (у 2012 році на $2,4 \%$, у 2013 році на $6,3 \%$ ).

З 2008 року інститут здійснює підготовку за кредитно-модульною системою організації навчального процесу на спеціальності 8.12010006 "Сестринська справа" освітньо-кваліфікаційного рівня "магістр".

Магістр медсестринства за освітньо-кваліфікаційними характеристиками істотно вирізняється від дипломованих медичних сестер та медсестер-бакалаврів. Специфікою магістрів за спеціальністю “Сестринська справа" $є$ те, що вимоги до навчальних програм концептуально мають забезпечували професійну спрямованість майбутніх викладачів сестринських дисциплін, системне вивчення ними загальної педагогіки, формування комунікативної компетенції, використання сучасних інноваційних технологій освіти для вибору оптимальної стратегії викладання спеціальних сестринських предметів залежно від рівня підготовки студентів.

Магістри медсестринства як майбутні керівники відділень сестринського догляду, хоспісів, професійні менеджери сестринської справи в практичній охороні здоров'я повинні вміти оцінювати, аналізувати дані, контролювати і здійснювати сестринський процес, встановлювати методи і пріоритети сестринських втручань, навчати персонал на робочому місці, вміти спілкуватись, працювати у команді.
Тому у вищих медичних навчальних закладах доцільним $€$ запровадження таких навчальних планів i програм, в яких буде враховано всі аспекти формування у студентів комунікативної компетентності, як важливої складової професійної компетенції лідера, наставника, керівника, координатора, науковця-дослідника, соціального маркетолога, а саме запровадження спецкурсів: "Викладання предметів у вищих медичних навчальних закладах" $\mathrm{i}$ “Методологія наукової роботи" для майбутніх викладачів сестринських дисциплін, “Лідерство в медсестринстві” для майбутніх менеджерів сестринської справи в практичній охороні здоров'я.

Наступною важливою складовою підготовки магістрів сестринської справи $€$ інтеграція навчального процесу з науково-дослідною роботою, яка передбачає формування у них наукової комунікативної компетентності.

Ми виокремлюємо три рівні наукової комунікативної компетентності магістра медсестринства:

- володіння комп'ютерними технологіями підвищення свого фахового рівня засобами Інтернету (прослуховування, лекцій on-line);

- використання комп'ютерних технологій у професійній (педагогічній і науковій) діяльності (використання інтерактивної дошки, участь on-line у вебінаpax тощо);

- створення об'єктів інтелектуальної власності (створення власного освітнього WEB-сайту, розробка програмного забезпечення для комп'ютерних 
центрів дистанційної освіти) та їх презентація у засобах масової комунікації.

Студенти магістратури не складають ліцензійного інтегрованого іспиту “Крок”, а результати їхньої на- вчальної і наукової діяльності оцінюються науководослідною роботою, доповідями і презентаціями на наукових форумах, захистом магістерської роботи.

Таблиця 1. Підготовка фахівців спеціальності 8.12010006 “Сестринська справа” освітньо-кваліфікаційного рівня “магістр"

\begin{tabular}{|c|c|c|c|c|c|}
\hline \multirow{2}{*}{ Назва показника } & \multicolumn{4}{|c|}{ Роки } & \multirow{2}{*}{ Разом } \\
\hline & 2010 & 2011 & 2012 & 2013 & \\
\hline Захищено магістерських робіт & 19 & 14 & 24 & 13 & 70 \\
\hline Середня оцінка за 5-бальною шкалою & 4,5 & 4,7 & 4,6 & 4,8 & 4,7 \\
\hline Кількість наукових публікацій & 95 & 70 & 120 & 65 & 350 \\
\hline Кількість доповідей на НПК & 57 & 42 & 72 & 39 & 210 \\
\hline Кількість доповідей на НПК за кордоном & - & 1 & 3 & 3 & 7 \\
\hline
\end{tabular}

В середньому впродовж 2-х років навчання кожен магістр друкує 5-6 робіт за результатами проведених наукових досліджень і не менше 3-х разів виступає з доповідями на різних наукових форумах міжнародного, державного і регіонального рівнів.

Підсумовуючи проведений аналіз, можна стверджувати, що введення кредитно-модульної системи дозволило інституту із року в рік істотно покращувати показники навчальної та наукової діяльності. Однак це не означає відсутності проблем.

Проблемні питання введення кредитно-модульної системи організації навчального процесу:

- відсутнє затверджене Міністерством освіти і науки України нове Положення про впровадження КМС у ВНЗ (програма проведення педагогічного експерименту щодо впровадження кредитно-модульної системи організації навчального процесу була передбачена на 2005-2008 pр.), яке визначало б основні напрямки подальшої діяльності;

- наявна трициклова система підготовки: молодший спеціаліст - бакалавр - магістр (відсутній наскрізний 4-річний план підготовки бакалаврів, відсутня можливість здобуття магістрами наукового ступеня); - відсутне нормативно-правове визначення щодо використання в практичній охороні здоров'я фахівців освітньо-кваліфікаційного рівня “бакалавр" та "магістр";

- проблеми мобільності студентів та викладачів пов'язані з недосконалим володінням іноземними мовами;

-більшістю навчальних планів підготовки, затверджених наказом Міністерства охорони здоров'я від
07.07.2011 року № 401, не передбачено вибір студентом навчальних дисциплін та можливість накопичення кредитів ECTS;

- студенти першого курсу не завжди психологічно підготовлені до КМС, яка передбачає самостійне вивчення значного об'єму матеріалу (до 50 \% від загального обсягу навчальних годин з дисципліни);

- невизначеність механізму проходження повторного курсу вивчення певних дисциплін для студентів, що отримали найнижчу оцінку - F за шкалою ECTS (чинними нормативними документами не визначено порядок реалізації цього положення);

- велике середнє навантаження на викладача у зв'язку з тим, що фактичне співвідношення викладач-студент складає 1:10 (КМС передбачає 1:5).

Висновок. Запровадження ступеневої медсестринської освіти за кредитно-модульною системою: дипломована медична сестра $\rightarrow$ медична сестра бакалавр $\rightarrow$ медична сестра - магістр за спеціальністю “Сестринська справа” стало прогресивним кроком у розвитку вищої професійної освіти в країні і необхідною умовою вдосконалення якості медсестринської допомоги населенню, а запровадження наукових досліджень у галузі сестринської справи важливим фактором вдосконалення змісту та форм медсестринської допомоги населенню, суті та перспектив медсестринської освіти.

Перспективи подальших розвідок у цьому напрямі полягають в поглибленому аналізі нових підходів до вдосконалення якості вищої медсестринської освіти. 


\section{Література}

1. Впровадження нових технологій за кредитно-модульної системи організації навчального процесу у ВМ(Ф)НЗ III-IV рівнів акредитації : матеріали Всеукр. наук. навч. метод. конф., присвяченої 55-річчю Тернопільського державного медичного університету (Тернопіль, 26-27 травня 2012 р.). -Тернопіль : ТДМУ, 2012. -600 c.

2. Модернізація вищої медичної освіти в контексті Болонської конвенції - ідея, мета та реалії / В. М. Мороз, Ю. Й. Гумінський, Л. В. Фоміна [та ін.] // Впровадження нових технологій за кредитно-модульної системи організації навчального процесу у ВМ(Ф)НЗ III-IV рівнів акредитації : матеріали Всеукр. наук. навч. метод. конф., присвяченої 55-річчю Тернопільського державного медичного університету.-Тернопіль : ТДМУ, 2012.-С. 33-35.

3. Особливості маркетингової політики вищого навчального закладу в умовах кредитно-модульної системи організації навчального процесу / В. М. Ждан, В. М. Бобирьов,
С. М. Білаш [та ін.] // Впровадження нових технологій за кредитно-модульної системи організації навчального процесу у ВМ(Ф)НЗ III-IV рівнів акредитації : матеріали Всеукр. наук. навч. метод. конф., присвяченої 55-річчю Тернопільського державного медичного університету. Тернопіль : ТДМУ, 2012.-С. 47-49.

4. Попередні підсумки запровадження кредитно-модульної системи організації навчального процесу у вищих медичних навчальних закладах та шляхи подальшого удосконалення його організації / В. В. Вороненко, О. П. Волосовець, Ю. С. П'ятницький [та ін.] // Впровадження нових технологій за кредитно-модульної системи організації навчального процесу у ВМ(Ф)НЗ III-IV рівнів акредитації : матеріали Всеукр. наук. навч. метод. конф., присвяченої 55-річчю Тернопільського державного медичного університету.-Тернопіль : ТДМУ,2012.-С. 11-16.

(C) О. Я. Попадюк 